\title{
Symptoms of hyperprolactinemia with normal serum prolactin: is treatment required?
}

\author{
Deepti Verma* \\ Department of Obstetrics and Gynecology, Mayo Institute of Medical Sciences, Barabanki, Uttar Pradesh, India
}

Received: 06 April 2016

Accepted: 07 May 2016

\section{*Correspondence:}

Dr. Deepti Verma,

E-mail: drdeepti86@gmail.com

Copyright: ( ) the author(s), publisher and licensee Medip Academy. This is an open-access article distributed under the terms of the Creative Commons Attribution Non-Commercial License, which permits unrestricted non-commercial use, distribution, and reproduction in any medium, provided the original work is properly cited.

\begin{abstract}
Galactorrhea with menstrual abnormalities like oligomenorrhea or amenorrhea point towards a provisional diagnosis of increased serum prolactin levels or hyperprolactinemia. However, as the prolactin hormone is heterogeneous with two forms- the bioactive and the immunoactive forms, patients can have all the features of hyperprolactinemia with normal serum prolactin levels.
\end{abstract}

Keywords: Hyperprolactinemia, Prolactin, Galactorrhea

\section{INTRODUCTION}

Galactorrhea is the inappropriate lactation (not associated with pregnancy or lactation) which can occur in $20-25 \%$ of the female population. ${ }^{1}$ An increased serum prolactin level due to various factors is the cause of galactorrhea in the majority of cases. Pituitary tumours, stress, hypothalamic lesion, drugs that inhibit dopamine release (antipsychotics etc.), oral contraceptive pills, all lead to increased levels of prolactin in the serum.

Oligomenorrhea and amenorrhea are the menstrual disturbances which can occur due to various hormonal disturbances like polycystic ovarian syndrome, Cushings syndrome, hypothyroidism and hyperproclatinemia. However, when these menstrual disturbances are associated with galactorrhea, hyperprolactinemia is strongly suspected.

In patients with both galactorrhea and oligomenorrhea/amenorrhea, approximately one third have hyperprolactinemia. ${ }^{2}$

Pulsatile secretion of gonadotropin releasing hormone $(\mathrm{GnRH})$ is inhibited by pathological hyperprolactinemia, leading to menstrual abnormalities.

\section{CASE REPORT}

A 38 years old lady with two live issues, last child birth 7 years back, presented to the gynecology outpatient department of Mayo Institute of Medical Sciences with the complains of oligomenorrhea and galactorrhea for last 6 months. Her previous menstrual cycles were normal and there was no abnormal breast secretion prior to that except during pregnancy and lactation. She had no vision abnormalities like diplopia or headache.

On breast examination, revealed milk discharge from bilateral breasts. On pelvic examination, uterus, cervix and bilateral adenexa were normal. Since she had oligomenorrhea and galactorrhea, serum prolactin and thyroid profile was advised. Ultrasound pelvis was also done which was normal. Her serum prolactin levels were $8.2 \mathrm{ng} / \mathrm{ml}$ by chemilumeniscence assay, which are normal limits. Her thyroid hormone levels were normal and ultrasound showed normal uterus, cervix and adenexa.

In view of her symptoms, she was advised tablet cabergoline $0.25 \mathrm{mg}$ biweekly, which she continued for 4 weeks. After 4 weeks, she was not relieved from galactorrhea, therefore the dose of cabergoline was increased to $0.5 \mathrm{mg}$ biweekly for 3 months. Her 
galactorrhea was relieved and she resumed her normal menstrual cycles four months after starting the treatment.

\section{DISCUSSION}

Galactorrhea with oligomenorrhea is symptoms which strongly point towards the diagnosis of hyperprolactinemia. However, in our case, the patient had these symptoms in the presence of normal prolactin levels. Similar case was reported by Agarwal $\mathrm{M}$ et al, in which the patient had galactorrhea and amenorrhea with normal serum prolactin levels. ${ }^{3}$ The reason for such discrepancy in symptoms and laboratory result is due to variable molecular heterogeneity of prolactin levels. Different forms have varying bioactivity (which manifest as symptoms like galactorrhea and menstrual abnormalities) and immunoreactivity (which leads to the laboratory result as recognized by the immunoassay). The predominant variant is little prolactin $(80-85 \%)$ which also has more biological activity than big prolactin. Macroprolactin or big prolactin is a complex of prolactin with immunoglobulin ( $\mathrm{IgG})$ that in vivo appears to have limited or no biological activity, possibly because of the failure of the high-molecular weight complex to cross capillary walls. ${ }^{4}$ Both the big and big-big forms of hyperprolactinemia have been reported mostly in women with idiopathic hyperprolactinemia and normal menstrual cycle and fertility. This is so because both the forms of big prolactin have decreased receptor affinity, while the big-big form of prolactin has decreased bioavailability. ${ }^{5}$

From the above case report and from the earlier studies (Eftekhan $\mathrm{N}$ et al and Agarwal $\mathrm{M}$ et al), it can be concluded that the patient with galactorrhea having normal serum prolactin levels should be considered for treatment if they are bothered by galactorrhea, menstrual irregularities or infertility. Several studies concluded that the trial of cabergoline or bromocriptine (prolactin lowering drugs) is worthwhile in women with unexplained infertility with galactorrhea. ${ }^{6}$

\section{CONCLUSION}

Knowledge of the basic molecular structure and function of various hormones can be of great help in treatment of such cases with diagnostic dilemma in clinical practice.

\section{Funding: No funding sources \\ Conflict of interest: None declared \\ Ethical approval: Not required}

\section{REFERENCES}

1. Kemmann E. Incidence of galactorrhoea. JAMA. 1976;236:2747.

2. Avner H, Mathew PC. Endocrine Disorders in Novak's Gynecology. In: Jonathan BS, editor. 13th ed. Philadelphia: Lippincott Williams and Wilkins; 2002. pp. 899

3. Agarwal M, Das A, Singh SA. Hyperprolactinemia with normal serum prolactin: Its clinical significance. J Hum Reprod Sci. 2010;3(2):111-2.

4. Leite V, Cosby H, Sobrinho LG, Fresnoza A, Santos AM, Friesen HG. Characterization of big, big prolactin in patients with hyperprolactinaemia. Clin Endocrinol (Oxf). 1992;37:365-72.

5. Tritos NA, Guay AT, Malarkey WB. Asymptomatic big hyperprolactinemia in two men with pituitary adenomas. Eur J Endocrinol. 1998;138:82-5.

6. Hughes E, Collins J, Vanderkerckhove P. Bromocriptine for unexplained subfertility in women. Cochrane Database Syst Rev. 2000;2:CD000044.

Cite this article as: Verma D. Symptoms of hyperprolactinemia with normal serum prolactin: is treatment required? Int J Reprod Contracept Obstet Gynecol 2016;5:2041-2. 